LISANUL ARAB 10 (1) (2021)
(Terakreditasi Sinta 4)
http://journal.unnes.ac.id/sju/index.ph/laa

\title{
MANAJEMEN PELAKSANAAN MATA PELAJARAN BAHASA ARAB MTS. HADIL ISHLAH
}

\author{
Ziki Al Gofari ${ }^{\bowtie}$, Laily Fitriani ${ }^{\bowtie}$
}

Universitas Islam Negeri Maulana Malik Ibrahim Malang

\section{Info Artikel \\ Sejarah Artikel: \\ Diterima Januari 2021 \\ Disetujui Maret 2021 \\ Dipublikasikan April 2021}

Keywords:

Management;

Implementation; Arabic

\begin{abstract}
Abstrak
Manajemen pelaksanaan mata pelajaran Bahasa Arab adalah usaha untuk mengarahkan, menggerakkan dan memotivasi anggota ataupun bawahannya dalam suatu organisasi untuk mencapai tujuan. dalam hal dalam hal ini kepala sekolah sebagai manajer di sekolah harus mampu mengarahkan, menggerakkan serta memotivasi guru bahasa Arab secara khusus dan umumnya staf atau guru-guru lain yang ada disekolah, selain itu juga guru sebagai pelaksana pembelajaran mata pelajaran bahasa arab juga harus mampu membuat pelaksanaan pembelajaran yang efektif dan menarik dengan menggunakan metode dan teknik yang mudah dipahami oleh siswa serta dapat memanfaatkan fasilitas dan media yang ada dan tidak kalah pentingnya yaitu guru harus mampu menguasai materi bahan ajar, Penelitian ini bertujuan untuk mengetahui bagaimana implementasi dan faktor-faktor yang mempengaruhi manajemen pelaksanaan di MTs. Hadil Ishlah, adapun metode penelitian yang digunakan ialah metode kualitatif dengan pendekatan studi kasus, dan teknik pengumpulan data yaitu dengan wawancara, observasi dan dokumentasi, hasil penelitian menjelaskan bahwa manajemen pelaksanaan mata pelajaran bahasa Arab di MTs. Hadil Ishlah meliputi tiga hal yaitu: 1) kepemimpinan, untuk tercapainya tujuan organisasi sekolah kepala sekolah sebagai manajer di sekolah selalu memberikan bimbingan, arahan, dan pengawasan, begitu juga dengan gaya kepemimpinan guru yang demokratis. 2) motivasi, selain kepala sekolah guru di sekolah juga selalu memberikan motivasi terhadap peserta didik baik itu berupa pujian, gaji, hadiah d1l. 3) komunikasi, adapun komunikasi yang digunakan disekolah sangatlah baik sehingga terjalinnya kerjasama yang baik antara anggota organisasi sekolah.
\end{abstract}

Abstract

Management of the implementation of Arabic subjects is an attempt to direct, mobilize and motivate members or subordinates in an organization to achieve goals. in this case the principal as a manager in the school must be able to direct, mobilize and motivate Arabic teachers in particular and generally staff or other teachers at school, besides that the teacher as the implementer of learning Arabic subjects must also be able to make implementation of effective and attractive learning using methods and techniques that are easy to understand by students and can take advantage of existing facilities and media and no less important, namely the teacher must be able to master the teaching material implementation management at MTs. Hadil Ishlah, the research method used is a qualitative method with a case study approach, and data collection techniques, namely by interview, observation and documentation, the results of the study explain that the management of the implementation of Arabic subjects in MTs. Hadil Ishlah includes three things, namely: 1) leadership, to achieve the goals of the school organization the principal as a manager in the school always provides guidance, direction and supervision, as well as a democratic teacher leadership style. 2) motivation, in addition to the principal, the teachers at the school also always provide motivation to students in the form of praise, salary, gifts, etc. 3) communication, as for the communication used at school is very good so that there is good cooperation between members of the school organization.

(C) 2021 Universitas Negeri Semarang

\begin{tabular}{lc}
\hline Alamat korespondensi: & P- ISSN 2252-6269 \\
Gedung B4 Lantai 1 FBS Unnes & E- ISSN 2721-4222 \\
Kampus Sekaran, Gunungpati, Semarang, 50229 & \\
E-mail: zikialgofari01@gmail.com; laily@bsa.uin-malang.ac.id &
\end{tabular}




\section{PENDAHULUAN}

Pelaksanaan adalah hubungan antar seseorang yang disebabkan oleh adanya peraturan dan pembagian pekerjaan kepada anggota supaya bisa dimengerti secara efektif dan efisien untuk tujuan organisasi yang nyata. Menurut terry (1978) berpendapat bahwa pelaksanaan ialah upaya untuk menggerakkan aggota organisasi agar mau berusaha untuk mencapai tujuan lembaga yang bersangkutan (Gunawan dan Benty, 2017: 81). Pelaksanaan dimaknai juga dengan usaha untuk membuat semua anggota yang ada didalam suatu organisasi mau bekerja sama supaya cita-cita dan tujuannya dapat dicapai dengan baik.

Pelaksanaan merupakan suatu fungsi yang sangat penting dalam proses manajemen, karena merupakan usaha untuk melakukan suatu tindakan, agar semua anggota terlibat mulai dari atasan hingga bawahan berusaha agar dapat mencapai tujuan suatu organisasi sesuai dengan rencana yang telah ditetapkan, secara baik dan benar. Oleh karena itu pelaksanaan itu merupakan sebuah operasionalisasi dari sebuah perencanaan. Fungsi Perencanaan dan organisasi juga sangat dibutuhkan, tetapi tidak akan ada hasil yang konkrit sehingga kita dapat mengimplemantasikan aktivitas-aktivitas yang direncanakan dan diorganisasikan.

Bahasa Arab memiliki peranan yang sangat penting didalam dunia pendidikan, karena untuk mendalami ilmu agama yang menjadi pondasi kehidupan dan untuk membentuk akhlak peserta didik, maka diperlukan keahlian bahasa Arab. Akan tetapi, fenomena yang terjadi saat ini bahwa masih kurangnya capaian hasil dari sebuah pelaksanaan mata pelajaran bahasa Arab oleh beberapa sekolah pada umumya, ini bisa dilihat dari kemampuan siswa yang masih kurang, salah satu penyebabnya yaitu kurangnya perhatian dalam sebuah manajemen, khususnya dalam sebuah pelaksanaan. Kenyataan ini tidak hannya terjadi di sekolah pada umunya, tetapi juga terjadi pada perguruan tinggi (Maujud, 2015: 21).

Didalam konteks pelaksanaan mata pelajaran bahasa Arab, maka peran seorang guru dan kepala sekolah sangatlah besar dalam membantu siswa agar siswa dapat menerima pelajaran bahasa Arab dengan baik. Diantaranya guru harus memahami teori-teori tentang bagaimana konsep manajemen pembelajaran bahasa Arab. Hal ini seperti apa yang di ungkapakan oleh WIjaya (2017) bahwa suksesnya lembaga pendidikan bahasa Arab itu tidak lepas dari sinergi antara teori dan praktik pelaksanaan manajemen bahasa Arab yang bagus. Dimana seorang guru dituntut paham betul tentang konsep manajemen pembelajaran bahasa Arab agar mampu mencapai tujuan dengan efektif juga efisien (Wijaya, 2017: 17). Guru juga harus mampu menjadi motivator bagi peserta didik. hal ini diungkapakan oleh Faiqoh (2017) bahwa dalam manajemen pembelajaran bahasa Arab, guru sebagai motivator harus mengabil peran dan modelnya sebagai pemberi arahan dan juga dukungan bagi peserta didik dalam proses pembelajaran bahasa Arab (Faiqoh, 2017: 84). Selain itu guru juga harus mampu menempatkan kedudukannya sebagai tenaga profesional dan harus mampu mengintegrasikan diri dengan komponenkomponen sekolah lainnya, sesuai dengan pernyataan Roviin (2017) bahwa guru memiliki tugas untuk mentransfer pengetahuan dan nilainilai. Dan juga membimbing peserta didik didalam proses pembelajaran. Maka dari itu guru harus menempatkan kedudukannya sebagai tenaga professional. Begitu pula kinerja guru akan optimal, jika adanya kerjasama yang baik dengan komponen-komponen sekolah, terutama dengan kepala sekolah. (Roviin, 2017: 176).

MTs. Hadil Islah merupakan salah satu madrasah yang akhir-akhir ini memiliki peningkatan dan banyak di minati masyarakat. Hal ini dapat dilihat dengan banyaknya siswasiswi yang datang dari berbagai daerah yang ada di daerah Lombok bahkan juga ada beberapa siswanya yang datang dari luar daerah diantaranya Sumbawa dan Bima. Selain itu juga madrasah ini memiliki prestasi dari segi keilmuan umum, keagamaan, dan juga kebahasaan khususnya dalam bahasa arab ini dapat dibuktikannya bahwa madrasah ini mampu meraih juara-juara diantaranyayaitu juara pertama dan kedua dalam lomba khitobah 
yang dilaksanakan di MAN 2 Mataram. karena itu madrasah ini mampu bersaing dengan sekolah-sekolah negeri maupun sekolah yang lain yang ada di pulau Lombok.

Bahasa Arab merupakan salah satu mata pelajaran yang diajarkan di MTs. Hadil Ishlah, peserta didik dituntut agar mampu berkomunikasi dengan baik menggunakan bahasa Arab secara lisan maupun tulisan, selain itu juga untuk menambah wawasan supaya mampu memperdalam ilmu-ilmu agama. Namun, masih terdapat beberapa peserta didik di MTs Hadil Ishlah ini masih kurang antusias dalam mengikuti pelaksanaan mata pelajaran bahasa Arab ini disebabkan karena mereka menganggap bahwa mata pelajaran ini termasuk mata pelajaran yang susah. Tentu hal ini menjadi sebuah problem yang nanti akan mempengaruhi hasil belajar mereka. Maka peneliti disini ingin mengetahui terkait dengan implementasi manajemen pelaksanaan mata pelajaran bahasa Arab dan juga faktor-faktor yang mempengaruhi manajemen pelaksanaan mata pelajaran bahasa Arab di MTs. Hadil Ishlah Bilebante Lombok.

\section{LANDASAN TEORI}

\section{Pengertian Manajemen Pelaksanaan}

Menurut James A.F. Stoner manajemen merupakan suatu proses yang dimulai dari perencanaan, pengorganisasian, pengarahan dan pengawasan dan penggunaan sumber daya organisasi untuk mencapai tujuan organisasi yang diinginkan (Gunawan dan Benty, 2017: 22).

Mary Parker Follet mengartikan manajemen sebagai seni untuk untuk mendapatkan sesuatu melalui orang lain, yang membutuhkan keterampilan khusus, seperti pandai mengarahkan, mempengaruhi, dan membina anggota agar melakukan pekerjaan yang diinginkan oleh seorang pemimpin agar bisa mencapai tujuan yang telah ditetapkan sebelumnya (Hikmat, 2009: 12)

Adapun pelaksanaan disebut juga dengan penggerakan. Maka dari itu pelaksanaan merupakan menggerakkan anggota atau bawahan agar mau bekerjasama dalam bekerja sehingga tercapainya tujuan suatu organisasi (Ruyatnasih dan Megawati, 2018: 95).

Pelaksanaan ialah fungsi manajemen yang erat hubungannya dengan proses manajemen dalam hal pelaksanaan tugas. Pendapat Kurniadin dan Machali (2012) tentang pelaksanaan ialah sebuah upaya untuk memulai, memberi motivasi, memprakarsai, dan memberi arahan kepada anggota untuk mengerjakan tugas-tugasnya demi tercapainya tujuan yang telah ditentukan oleh suatu organisasi (Gunawan dan Benty, 2017: 81).

Sedangkan menurut soepardi (1998) pelaksanaan merupakan usaha atau upaya untuk menggerakkan atau mengarahkan menpower (tenaga kerja) seta mendayagunakan fasilitas yang ada (Gunawan dan Benty, 2017: 81).

Pelaksanaan atau penggerakan (actuating) dalam sebuah pendidikan dapat dilakukan setelah suatu lembaga pendidikan memiliki perencanaan dan melakukan pengorganisasian dengan struktur organisasi yang jelas serta tersedianya anggota sebagai pelaksana sesuai kebutuhan satuan kerja yang dibentuk. Adapun kegiatan dalam pelaksanaan adalah memberikan pengarahan (commanding), bimbingan (directing), motivasi (motivating) dan komunikasi (communicating). Jikalau suatu organisasi lembaga pendidikan telah berfungsi, setiap anggota sudah siap melaksanakan tugasnya sesuai dengan tanggung jawab dan wewenang masing-masing, Maka tentu diperlukannya pengarahan dan bimbingan secara terus menerus dari kepala sekolah sebagai pimpinan tertinggi dalam sebuah lembaga pendidikan agar pelaksanaannya dapat dilakukan secara efektif, efisien dan terarah dalam mencapai tujuan organisasi.

Dari beberapa pengertian diatas dapat disimpulkan bahwasanya Manajemen Pelaksanaan merupakan serangkaian kegiatan atau usaha yang berkaitan dengan mengarahkan, menggerakkan dan memotivasi yang dilakukan oleh seorang pemimpin terhadap anggota ataupun bawahannya dalam suatu organisasi untuk mencapai tujuan yang sudah direncanakan sebelumnya secara efektif serta efisien. 
Jika dikaitkan dengan manajemen pelaksanaan mata pelajaran bahasa Arab maka dalam hal dalam hal ini kepala sekolah sebagai manajer di sekolah harus mampu mengarahkan, menggerakkan serta memotivasi guru bahasa Arab secara khusus dan umumnya staf atau guruguru lain yang ada disekolah, selain itu juga guru sebagai pelaksana pembelajaran mata pelajaran bahasa arab juga harus mampu membuat pelaksanaan pembelajaran yang efektif dan menarik dengan menggunakan metode dan teknik yang mudah dipahami oleh siswa serta dapat memanfaatkan fasilitas dan media yang ada dan tidak kalah pentingnya yaitu guru harus mampu menguasai materi bahan ajar. Sehingga dengan demikian guru dapat dikatakan sebagai guru yang profesional (Suyanto dan Djihad, 2013: 31).

\section{Tujuan Manajemen Pelaksanaan}

Tujauan pelaksanaan dalam organisasi adalah upaya seorang pemimpin dalam menciptakan keinginan, kemampuan dan menjadikan anggota tahu akan pekerjaan dan tugasnya sebagai bawahan dengan demikian secara sadar melakukan tugasnya sesuai rencana yang telah dibuat.

Diantara tujuan manajemen pelaksanaan pembelajaran sebagai berikut:

1) Membangun kerja sama antar anggota organisasi yang lebih efisien

2) Mengembangkan keterampilan dan kemampuan anggota organisasi

3) Menciptakan rasa menyukai dan menumbuhkan rasa memiliki pekerjaan pada diri anggota

4) Meningkatkan motivasi dan prestasi kerja staf dengan cara membuat suasana lingkungan kerja yang baik dan harmonis

5) Mengembangkan organisasi yang dinamis

6) Mengetahui lancar tidaknya suatu pekerjaan

7) Untuk melakukan perbaikan dan pencegahan terhadap kesalahan yang dibuat oleh anggota agar kesalahan tersebut tidak terulang kembali, dan juga agar tidak membuat kesalahan baru.
8) Menyesuaikan antara program (tingkat pelaksanaan) dan pelaksanaan biaya sudah sesuai dalam perencanaan yang telah dibuat sebelumnya atau tidak

9) Untuk mengetahui kesesuaian antara pelaksanaan kerja dengan kebijakan dan prosedur yang telah disepakati sebelumnya (Sukmadi, 2017: 90).

\section{Fungsi dan Unsur Manajemen Pelaksanaan}

Pelaksanaan suatu organisasi dan penggunaan alat-alat yang bagaimanapun canggihnya akan dapat terlaksana jika seluruh elemen ataupun anggota organisasi ikut aktif berperan dalam pelaksanaannya. Sama halnya dengan Fungsi pelaksanaan ini dapat kita ibaratkan seperti kunci stater motor, maksudnya ialah motor akan dapat berjalan jikalau kunci stater motor tersebut sudah menjalankan fungsinya. Begitupula dengan suatu manajemen itu akan terlaksana jika fungsi pelaksanaan ini telah dilakukan.

Fungsi pelaksanaan merupakan upaya untuk meciptakan kerjasama yang baik antara anggota pelaksana organisasi baik itu pemimpin maupun anggota (staf) sehingga sasaran dari organisasi tersebut tercapai sesuai rencana secara efektif dan efisien. Didalam pelaksanaan ini haruslah dimulai dari seorang pemimpin (manajer) dengan menunjukkan kepada anggota bahwa dia mempunyai tekat yang kuat untuk mencapai kemajuan dan peka terhadap lingkungannya. Ia harus bisa bersikap obyektif dan mampu bekerjasama (Ruyatnasih dan Megawati, 2018: 97).

Berikut ini terdapat beberapa fungsi manajemen pelaksanaan:

\section{1) Coordinating}

Terry (1987) berpendapat bahwa koordinasi merupakan mengambil tindakan yang tepat dengan menyinkronisasi usaha seseorang yang berhubungan dengan jumlah, waktu dan tujuan mereka agar tujuan yang ditetapkan dapat tercapai (Gunawan dan Benty, 2017: 92). Untuk membantu mencegah adanya kekacauan atau percekcokkan dan juga terjadinya kekosongan 
kegiatan, maka menjalin kerjasama yang baik, terarah serta penyelarasan pekerjaan anggota dengan memberikan instruksi, perintah, membimbing dan menasehati jika terjadinya penyimpangan, serta mengadakan pelatihapelatihan agar dapat menambah wawasan adalah bentuk usaha untuk mencapai tujuan organisasi.

\section{1) Motivating}

Motivasi adalah bagian yang terpenting dalam manajemen pelaksanaan. Setiap anggota organisasi harus memiliki motivasi yang baik agar organisasi dapat mencapai tujuannya dengan baik. Kualitas prilaku yang ditampilkan seseorang baik dalam konteks bekerja atau dalam kehidupan sehari-harinya ditentukan oleh seberapa kuat motivasi yang dimiliki. Menurut certo (2012) Motivasi adalah keadaan batin yang menyebabkan sesorang agar berprilaku baik sehingga tercapainya tujuan yang ingin dicapai (Wijaya dan Rifa'i, 2016: 126 ).

Motivasi adalah power atau dorongan yang terdapat pada pribadi diri seseorang agar tercapainya suatu tujuan. Dorongan yang ada pada diri seseorang biasanya dipengaruhi lingkungan organisasi dan dirinya sendiri. Maka dari itu manajer atau pemimpin harus dapat menciptakan dan menjaga motivasi seorang anggota atau bawahan agar mereka dapat bekerja dengan semangat yang tinggi sehingga tujuan organisasi dapat tercapai secara maksimal.

\section{2) Communication}

Komunikasi merupakan elemen yang sangat penting dalam suatu organisaisi, dengan terjalinnya komunikasi yang baik antara pimpinan dan anggota akan membuat suasana kerja yang kondusif sehingga tercapainya tujuan suatu organisasi.

Menurut lewis (1987) komunikasi adalah pertukaran pesan antara individu yang menghasilkan pertukaran makna. Hal yang demikian berlangsung dalam kehidupan kita baik dalam konteks kehidupan sosial ataupun dalam konteks berorganisasi (Wijaya dan Rifa'i, 2016: 146).
Keberhasilan komunikasi dilihat dari bagaimana respon dari penerima pesan. Oleh sebab itu komunikasi yang efektif, apabila kita mendengarkan dan mengerti apa yang dikatakannya. Sesuai dengan yang dijelaskan oleh lewis (1978) bahwa "I hear you, I understand what you're saying" (Rifa'I dan Fadli, 2013: 126).

\section{3) Commanding}

Komando adalah perintah atau intruksi kepada anggota dalam menjalankan tugas masing-masing agar dapat terlaksana dengan baik dan mencapai tujuan yang telah ditentukan (Gunawan dan Benty, 2017: 93).

Komando berarti seorang atasan memeberikan perintah terhadap anggota dengan memperhitungkan langkah-langkah dan resiko setiap keputusan yang diambil, karena akan berdampak bagi organisasi.

\section{METODE PENELITIAN}

1) Jenis penelitian

Penelitian ini merupakan penelitian studi kasus yang mana diartikan sebagai metode atau strategi dalam penelitian untuk mengungkap kasus tertentu. Penelitian ini merupakan jenis penelitian lapangan (field research) yang informasinya diperoleh dari responden atau subjek penelitian dengan menggunakan instrument untuk mengumpulkan data seperti wawancara, observasi dan sebagainya (Suharsimi, 1998: 130). Dilihat dari segi datanya penelitian ini termasuk penelitian kualitatif yaitu menghasilkan data deskriptif berupa pendapat atau opini berupa narasi dalam kalimat atau paragaraf dari orang-orang atau perilaku yang diamati (Lexy J. Moloeng, 2002: 6).

\section{2) Data dan Sumber data}

Dalam suatu penelitian terdapat dua sumber data (Abdul gafur dkk, 2020: 94) yaitu:

\section{a) Sumber data primer}

Sumber data primernya diambil langsung dari hasil wawancara dengan beberapa pihak seperti, kepala sekolah, waka kurikulum, guru dan sisiwa yang ada di MTs. Hadil Ishlah dan 
juga hasil pengamatan terkait proses berlangsungnya manajemen pelaksanaan mata pelajaran bahasa Arab.

b) Sumber data sekunder

Sumber data sekundernya berupa dokumen-dokumen tertentu.

Data yang diambil dalam sebuah penelitian ini sesuai dengan sumber data yang sudah dijelaskan diatas yaitu:

\section{a) Data primer}

Data primer dalam penelitian ini adalah hasil wawancara dan observasi langsung ke lapangan terkait manajemen pelaksaan mata pelajaran bahasa Arab.

\section{b) Data skunder}

Data skunder berupa dokumen tertentu terkait manajemn pelaksaan mata pelajaran bahasa Arab seperti data guru pengajar, data siswa dll.

\section{Teknik pengumpulan data}

Didalam penelitian ini terdapat tiga teknik pengumpulan data yang peneliti gunakan:

a) Observasi

Observasi yang peneliti lakukan didalam penelitian ini adalah pengamatan terhadap manajemen pelaksanaan mata pelajaran bahasa Arab di MTs. Hadil Ishlah.

\section{b) Wawancara}

Wawancara yang peneliti lakukan adalah untuk memperoleh data data yang akurat dan sumber data yang tepat. Disini peneliti mewancarai 4 orang yang terlibat didalamnya yaitu kepala sekolah, waka kurikulum, guru mata pelajaran bahasa Arab dan siswa

c) Dokumentasi

Teknik dokumentasi merupakan teknik pengumpulan data yang mana datanya didapatkan dari sumber selain manusia, bisa berupa dokumen, foto, jadwal kegiatan dll (Mamik, 2015: 115).

\section{Teknik validasi data}

Peneliti dalam menguji validasi data menggunakan beberapa teknik diantaranya:

a) Perpanjang pengamatan

Maksudnya yaitu peneliti melakukan pengamatan tidak hanya sekali saja akan tetapi lebih, sehingga hubungan antara peneliti dan objek penelitian akan dekat dan akrab sehingga tidak adaa data yang terlewatkan (mamik, 2015: 191)

b) Meningkatkan ketekunan

Melakukan pengamatan lebih cermat dan berkesinambungan, sehingga kepastian data dan urutan peristiwa dapat direkam secara pasti dan sistematis (mamik, 2015: 191)

c) Triangulasi teknik

Pada penelitian ini peneliti hannya menggunakan teknik pemeriksaan dengan memanfaatkan sumber. Triangulasi dengan sumber adalah mengecek data yang sama dengan teknik yang berbeda yaitu melalui waktu dan alat yang berbeda(Abdul gafur dkk, 2020: 94).

\section{Teknik analisis data}

Teknik analisis data yang digunakan adalah teknik analisa deskriptif yaitu suatu analisa yang menjelaskan fakta data sebagaimana apa adanya terpisah dari perspektif subyektif. Metode ini digunakan untuk menganalisa data-data yang bersifat kualitatif (Muhajir, 1997: 102). Terdapat tiga langkah dalam menganalisis data adalah sebagai berikut: a) Reduksi data, yaitu memilih, menyederhanakan data yang diperoleh dilapangan untuk ditarik kesimpulan final untuk selanjutnya diverifikasi. b) Pemaparan data, Pemaparan disini dibatasi sebagai pemaparan sekumpulan informasi tersusun yang memberi kemungkinan adanya penarikan kesimpulan. Dan c) Verification, merupakan menarik kesimpulan dari data-data yang sudah ada kemudian kesimpulan tersebut dilakukan verifikasi sebagai hasil analisis data. 


\section{HASIL PENELITIAN}

Didalam pembahasan hasil penelitian ini didasari pada analisis data-data penelitian yang diproleh dari hasil wawancara dan observasi. Diharapkan dengan pemerolehan data tersebut dapat menghasilkan pembahasan secara menyeluruh dan mendalam pada penelitian ini.

Adapun hasil data temuan yang berkaitan dengan Manajemen Pelaksanaan Mata Pelajaran Bahasa Arab di MTs. Hadil Ishlah meliputi implementasi manajemen pelaksanaan serta factor pendukung dan penghambat dalam manajemen pelaksanaan.

Implementasi Manajemen Pelaksanaan Mata Pelajaran Bahasa Arab di MTs. Hadil Ishlah

Dalam implementasi manajemen pelaksanaan mata pelajaran bahasa Arab di MTs. Hadil Ishlah ini mencakup beberapa hal diantaranya:

\section{1) Kepemimpinan (leadership)}

Kepemimpinan (leadership) adalah suatu seni yang harus dimiliki seorang pemimpin dalam mempengaruhi serta mengarahkan bawahannya agar dapat melakukan tugastugasnya sesuai dengan ketentuan yang telah dibuat sehingga tercapainya tujuan suatu organisasi.

Manajemen pelaksanaan mata pelajaran bahasa Arab merupakan serangkaian kegiatan atau usaha yang berkaitan dengan mengarahkan, menggerakkan dan memotivasi yang dilakukan oleh seorang pemimpin terhadap anggota ataupun bawahannya dalam suatu organisasi didalam pembelajaran mata pelajaran bahasa Arab agar tercapainya tujuan yang sudah direncanakan sebelumnya secara efektif serta efisien. Sehubungan dengan itu kepala sekolah sebagai manajer yang memiliki tugas penting untuk menggerakkan semua komponen yang terlibat dalam sekolah seperti guru, staf dan peserta didik untuk mencapai tujuan pendidikan sekolah. Dan guru adalah orang yang ditugaskan untuk membantu peserta didik dalam menerima ilmu yang diajarakan sehingga mampu mengembangkan potensi yang ada didalam dirinya.
Didalam hal ini upaya yang dilakukan kepala sekolah MTs. Hadil Ishlah sebagai pemegang jabatan tertinggi didalam organisasi sekolah (manajer), sesuai dengan hasil wawacara bersama kepala sekolah setempat bahwa beliau selalu memberikan arahan dan bimbingan kepada staf, guru dan peserta didik terkait dengan tugas-tugas mereka. Adapun bentuk arahan dan bimbingan yang diberikan kepada guru atau staf ialah seperti memberikan saran dan nasihat terkait kinerja mereka yang dianggap kurang baik, sehingga terciptanya situasi kerja yang baik, nyaman tanpa tekanan sehingga semua merasa diperhatikan oleh kepala sekolah. Sedangkan bentuk bimbingan yang diberikan ialah berupa pelatihan-pelatihan terkait pelaksanaan pembelajaran dan bisa juga dalam bentuk memberikan contoh teladan yang baik. Hal ini dikuatkan oleh Finch dan McGought yang mengatakan bahwa tugas seorang pemimpin ialah memberikan pengarahan dan bimbingan (Gunawan dan Benty, 2017: 89).

Tugas kepala sekolah tidak jauh berbeda dengan tugas wakil kepala bidang kurikulum, dimana didalam pelaksanaan ini beliau melakukan pengawasan untuk mengontrol serta membantu guru-guru dalam menemukan dan mengatasi hambatan atau kesulitan agar kurikulum dapat berjalan sesuai dengan tujuannya. Adapun bentuk pengawasan yang dilakukan ialah mengawasi berjalannya kegiatan proses belajar mengajar, apakah seorang guru sudah melakukan langkah-langkah pembelajaran sesuai dengan rencana pelaksanaan pembelajaran yang sudah dibuat sebelumnya. Demikian ini sesuai dengan fungsi dari pengawasan itu sendiri yaitu untuk memastikan anggota organisasi (guru) melaksanakan apa yang menjadi tugasnya dengan mengumpulkan, menganalisis serta mengevaluasi informasi serta memanfaatkannya untuk megendalikan suatu organisasi (Hasibuan, melayu, 2007: 197). Akan tetapi di MTs. Hadil Ishlah ini jarang dilakukan karena menurut kepala sekolah dan wakil kepala bidang kurikulum bila terlalu sering dilakukan dapat mengganggu suasana pembelejaran sehingga pengawasan yang dilakukan sewaktuwaktu saja bila sangat diperlukan. 
Didalam manajemen pelakasanaan mata pelajaran bahasa Arab tidak hannya kepala sekolah dan wakil kepala bidang kurikulum yang memiliki peranan penting akan tetapi gaya kepemipinan seorang guru juga tidak kalah pentingnya, mengingat bahwa hal tersebut dapat berpengaruh terhadap bagaimana gaya belajar dan hasil belajar peserta didik. Melihat hasil observasi yang telah dilakukan oleh peneliti bahwa didalam proses pembelajaran yang di lakukan oleh ibu leni warida selaku guru bahasa Arab di MTs. Hadil Ishlah cendrung menggunakan gaya kepemimpinan yang demokratis, dimana didalam proses pembelajaran beliau selalu mengajak peserta didik untuk ikut berpartisipasi dalam menyumbangkan gagasan dan idenya dalam mencapai tujuan pembelajaran. Hal ini sesuai dengan apa yang beliau lakukan ketika beliau mengajar, didalam proses belajar mengajar beliau menyuruh peserta didik untuk mencari kosakata yang belum diketahui terlebih dahulu di dalam kamus, jika terdapat peserta didik yang sudah mengetahuinya guru menyuruh mereka untuk memberitahukan kepada temennya yang belum mengetahuinya dan jika tidak ada satupun yangmengetahi maka beliau mempersilahkan peserta didiknya untuk bertanya dan seterusnya.

\section{2) Motivasi}

Motivasi merupakan prilaku yang harus dimiliki oleh seorang pemimpin agar dapat mempengaruhi bawahannya utuk dapat bekerja sesuai dengan tugas-tugas mereka. Kemampuan seorang pemimpin untuk memotivasi bawahannya tentu sangat menentukan kepuasan kerja mereka, oleh karena itu motivasi sangatlah penting untuk meningkatkan kinerja guru.

Menurut kepala sekolah di MTs. Hadil Ishlah motivasi merupakan suatu perangsang agar bawahan mau bekerja sesuai dengan tugasnya bahkan lebih. Maka dari itu beliau berpendapat bahwa motivasi ini sangatlah diperlukan. Adapun bentuk motivasi yang beliau berikan adalah berupa ungkapan pujian, gaji dan bonus-bonus seperti biasanya berbentuk sembako dll. hal ini beliau lakukan semata-mata untuk membangkitkan semangat dan mendorong para staf dan guru agar dapat bekerja secara optimal, efektif dan efisien. Hal ini dipertegaskan oleh sardiman (1996) dalam fungsi motivasi sebagai pendorong manusia untuk berbuat, disini motivasi sebagai penggerak disetiap tindakan yang akan di kerjakan (Suprihatin, 2015: 81)

Proses pembelajaran akan dikatakan berhasil jika peserta didik mempunyai motivasi didalam belajar. Maka dari itu guru harus mampu memberikan motivasi kepada peserta didiknya agar hasil belajarnya membuahkan hasil yang optimal maka dari itu, guru dituntut untuk kretif dalam membangkitkan motivasi belajar peserta didik. Sebagaimana yang dipaparkan oleh ibu Leni Warida bahwa bentuk motivasi yang diberikan guru di MTs. Hadil Ishlah ini ialah berupa ungkapan pujian, kemudian nilai, dan kadang memberikan apresiasi berupa hadiah bagi mereka yang memiliki kemampuan dalam menyelesaikan tugas dengan baik.

\section{3) Komunikasi}

Komunikasi diartikan sebagai proses pemindahan gagasan atau informasi dari seseorang ke orang lain. Komunikasi antara elemen sekolah sangat diperlukan untuk mencapai tujuan organisasi sekolah. Apabila setiap anggota organisasi dapat menjalin komunikasi yang baik maka akan menimbulkan suasana kerja yang kondusif dan juga akan dapat menumbuhkan rasa kerjasama yang baik dalam kegiatan organisasi.

Komunikasi antara kepala sekolah beserta guru-guru yang ada di MTs. Hadil Ishlah ini sudah sangat baik melihat bagaimana tutur mereka yang sopan dengan bagaimana mereka merespon kepada yang lebih tua ataupun kepada yang lebih muda dan tidak hannya itu selain meraka bisa berkomunikasi secara langsung disekolah mereka juga mebangun komunikasi diluar sekolah melalui whatsup grup sehingga informasi yang mereka dapatkan begitu cepat tanpa harus menunggu untuk bertemu tatap muka disekolah, hal ini dibuktikan dengan hasil wawancara saya dengan guru bahasa arab setempat yang mengatakan bahwa komunikasi yang terjalin di madrasah kita saat ini sangat baik 
dengan adanya whatsup grup ini, Kita sebagai guru tidak dikagetkan dengan informasiinformasi terkait sekolah yang urgen sehingga kita dapat mempersiapkannya dari rumah.

Komunikasi dalam proses belajar mengajar tentu dibutuhkan komunikasi yang baik juga baik itu dari segi bahasa yang dituturkan oleh seorang guru, sehingga peserta didik sebagai penerima informasi dapat menerima informasi dengan mudah sehingga tujuan dari proses pembelajaran dapat dicapai dengan baik. Komunikasi yang ada didalam pelaksanaan pembelajaran bahasa Arab tentu berbeda dengan yang lain, karena didalam pembelajaran mata pelajaran bahasa Arab harus adanya komunikasi menggunakan bahasa arab atau menciptakan lingkungan berbahasa arab agar peserta didik mampu dalam berkomunikasi menggunakan bahasa Arab. Akan tetapi di MTs. Hadil Ishlah ini jarang bahkan dianggap tidak pernah ini sesuai dengan hasil wawancara saya dengan salah seorang peserta didik yaitu Nawa Sila dia mengatakan bahwa guru bahasa arabnya didalam mengajar tidak pernah menggunakan bahasa Arab.

\section{Pelaksanaan Pembelajaran Bahasa Arab}

Dalam pelaksanaan pembelajaran bahasa Arab di kelas, dalam hal ini guru memfokuskan perhatian pada interaksi dengan peserta didik dalam proses pembelajaran. Maka dari itu pelaksanaan pembelajaran di dalam kelas terbagi menjadi tiga tahap, yaitu persiapan, pelaksanaan dan penutupan.

\section{1) Persiapan}

Sebelum memulai pembelajaran, yang dilakukan antara lain:

a) Mengucapkan salam dilanjutkan sapaan kepada siswa.

b) Memperhatikan semua kondisi yang ada di dalam kelas.

c) Melakukan absensi.

d) Memeriksa kondisi kesiapan siswa.

\section{2) Pelaksanaan}

kegiatan interaksi langsung dengan siswa mengenai materi yang diajarkan. Pelaksanaan pembelajaran ini dibagi menjadi tiga tahap:

a) Pendahuluan, yaitu diawali dengan mengarahkan perhatian untuk masuk ke pokok bahasan yang dilakukan dengan apersepsi atau mengajukan pertanyaan.

b) Kegiatan inti, adalah guru memulai proses pembelajaran dengan metode yang sesuai dengan keterampilan yang ingin dicapai.

c) Evaluasi, disini guru memberikan pertanyaan-pertanyaan mengenai pelajaran yang sudah di pelajari ataupun memberikan tugas rumah.

\section{3) Penutupan}

Kegiatan guru yang dilakukan setelah selesai melaksanakan tugas mengajarnya. Diantaranya penyampaian pesan, motivasi dan ucapan salam.

Dalam pelaksanaan pembelajaran di kelas, seorang guru bahasa Arab juga mengisi buku KBM dan juga buku kemajuan peserta didik dalam belajar bahasa Arab.

\section{Faktor Pendukung dan Penghambat Implementasi Manajemen Pelaksanaan Mata Pelajaran Bahasa Arab di MTs. Hadil Ishlah}

Terdapat beberapa factor yang menjadi pendukung dalam manajemen pelaksanaan mata pelajaran bahasa Arab di MTs. Hadil Ishlah diantaranya yaitu:

1) Adanya kesadaran yang kuat dari semua elemen sekolah baik itu dari kepala sekolah dan bawahan-bawahannya ini dapat dibuktikan dengan besarnya antusias dalam melaksanakan tugasnya masing-masing.

2) Adanya dukungan dari para guru untuk kepala sekolah dalam pengambilan kebijakan, sehingga kebijakan yang diambil dapat dipertanggung jawabkan bersama.

3) Adanya guru yang bertugas disekolah ini sesuai dengan bidangnya, seperti guru bahasa Arab dimana gurunya merupakan lulusan serjana bahasa Arab sehingga tujuan yang akan dicapai khususnya dalam mata 
pelajaran bahasa Arab dapat tercapai dengan baik.

4) Adanya rasa memiliki dan tanggung jawab yang besar dari para guru dan kepala sekolah, sehingga apa yang diberikan kepada sekolah tentunya yang terbaik, baik itu tenaga maupun pikiranya.

5) Adanya kesadaran dari siswa dan guru bahwa mata pelajaran bahasa Arab itu penting, mengingat bahwa bahasa Arab merupakan bahasa yang dapat digunakan untuk mendalami buku-buku agama dan lain sebagainya.

Sedangkan factor penghambat dalam manajemen pelaksanaan mata pelajaran bahasa Arab di MTs. Hadil Ishlah antara lain:

1) Kurangnya kemampuan bahasa Arab kepala sekolah sehingga kepala sekolah kurang menguasai bagaimana memanej pelaksanaan mata pelajaran bahasa arab dengan baik.

2) Kurangnya kesadaran yang dimiliki oleh sebagian guru dalam melaksanakan tugas yang menyebabkan tujuan organisasi sekolah tidak didukung sepenuhnya. Contohnya dalam belajar bahasa Arab disini guru masih mengajarkan kepada peserta didik tidak sesuai dengan rencana pelaksanaan pembelajaran yang sudah dibuat.

3) Kurangnya fasilitas sekolah untuk mendukung pelaksanaan pembelajaran mata pelajaran bahasa Arab seperti lab bahasa, buku-buku bacaan tentang bahasa arab dll.

4) Banyaknya peserta didik yang masih kurang mampu membaca huruf-huruf Arab sehingga pembelajaran bahasa Arab menjadi kurang efektif sehingga tujuan pembelajarannya sulit untuk tercapai.

Adapun upaya-upaya yang dilakukan pihak sekolah untuk mengatasi hambatanhambatan didalam manajemen pelaksanaan mata pelajaran bahasa Arab diantara ialah:

1) Memberikan wewenang sepenuhnya kepada guru-guru maupun staf sekolah yang memiliki kemampuan dalam bidang bahasa
Arab untuk memanajemen mata pelajaran bahasa Arab, karena kepala menganggap mereka memiliki kemampuan dalam hal itu.

2) Selalu mengingatkan dan membimbing guru agar pembelajaran yang dilakukan harus sesuai dengan rencana pelaksanaan pembelajaran yang telah dibuat, mengingat hal itu sangat penting agar tujuan pembelajaran dapat dicapai sesuai dengan apa yang direncanakan.

3) Memberikan fasilitas sederhana seperti menyiapkan wireless yang digunakan oleh guru untuk latihan istima', sedangkan untuk melatih keterampilan-keterampilan yang lain cukup dilakukan didalam kelas saja.

4) Mengelompokkan peserta didik yang belum mampu membaca huruf-huruf bahasa arab ataupun yang belum mampu membaca Alquran untuk dibimbing khusus.

Berdasarkan hasil wawancara peneliti diketahui adanya upaya yang dilakukan oleh kepala sekolah maupun guru untuk mengatasi hambatan-hambatan didalam manajemen pelaksanaan mata pelajaran bahasa Arab dibuktikan dengan adanya kesadaran dan tanggung jawab penuh dari semua pihak yang terlibat dalam organisasi sekolah.

\section{Kesimpulan}

Dari hasil penelitian diatas dapat disimpulkan bahwa manajemen pelaksanaan mata pelajaran bahasa Arab di MTs. Hadil Ishlah meliputi tiga hal yaitu: 1) kepemimpinan, untuk tercapainya tujuan organisasi sekolah kepala sekolah sebagai manajer di sekolah selalu memberikan bimbingan, arahan, dan pengawasan, begitu juga dengan gaya kepemimpinan guru yang demokratis. 2) motivasi, selain kepala sekolah guru disekolah juga selalu memberikan motivasi terhadap peserta didik baik itu berupa pujian, gaji, hadiah d11. 3) komunikasi, adapun komunikasi yang digunakan disekolah sangatlah baik sehingga terjalinnya kerjasama yang baik antara anggota organisasi sekolah.

Selain itu terdapat beberapa factor yang menjadi pendukung dan penghambat dalam manajemen pelaksanaan mata pelajaran bahasa 
Arab di MTs. Hadil Ishlah yang mana factor pendukungnya antara lain: a) memiliki rasa kesadaran dan tanggung jawab yang tinggi dari semua anggota organisasi, b) adanya dukungan dari semua elemen dalam mengambil kebijakan, c) adanya guru yang memiliki keahlian sesuai dengan bidang atau tugasnya, dan d) adanya kesadaran bahwa mata pelajaran bahasa Arab itu sangat penting. Selain itu juga terdapat factor yang menjadi penghambat diantaranya: a) kurangnya kemampuan kepala sekolah didalam memanaj mata pelajarana bahasa Arab, b) kurangnya sebagian guru dalam melaksanakan tugas, c) kurangnya fasilitas sekolah sebagai pendukung pelaksanaan pembelajaran mata pelajaran bahasa Arab, dan d) banyaknya peserta didik yang belum mampu memmbaca Alquran dengan baik. Begitu juga adanya upaya dari semua pihak untuk mengatasi hambatan tersebut diantaranya: a) memberikan wewenang kepada guru maupun staf dalam memanajemen mata pelajaran bahasa Arab, b) memeberikan bimbingan kepada guru terkait rencana pelaksanaan pembelajran, c) menyediakan fasilitas seadanya, dan d) mengelompokkan dan membimbing peserta didik yang belummampu membaca Alquran atau huruf-huruf arab.

\section{DAFTAR PUSTAKA}

Gunawan, imam dan Djum Djum Noor Benty, 2017, MANAJEMEN PENDIDIKAN Suatu Pengantar Praktik, Bandung,: CV Alfabeta

Hasibuan, Melayu S.P, 2001, Organisasi dan Motivasi, Jakarta: PT Bumi Aksar.

Hasibuan, Melayu S.P, 2007, Manajemen: Dasar, Pengertian dan Masalah, Jakarta: PT. Bumi Aksara
Hikmat, 2009, Manajemen Pendidikan, Bandung: CV PUSTAKA SETIA.

Mamik, 2015, metodologi kualitatif, sidoarjo: Zifatama publisher.

Maujud, Fathul, 2015, Manajemen Pembelajaran Bahasa Arab, Mataram: CV. Sanabil.

Moloeng, Lexy J. 2002. Metodologi Penelitian Kualitatif, Bandung: Remaja Rosdakarya.

Muhajir, Noeng, 1997. Metode Penelitian Kualitatif, Yogyakarta: Bumi Aksara.

Rifa'i, Muhammad dan Muhammad Fadli, 2013, Manajemen Organisasi, Bandung: Citapustaka Media Perintis.

Sukmadi, 2017, Dasar-Dasar Manajemen, Bandung: Humaniora Utama Press.

Suyanto dan Asep Djihad, 2013 Calon Guru dan Guru Profesional, Wonosari: Multi Pressindo

Wijaya, Candra dan Muhammad Rifa'i, 2016, DasarDasar Manajemen mengoptimalkan pengelolaan organisasi secara efektif dan efisien, Medan:

Gafur, Abdul, Nurhasan, Endang Switri, "Implementasi Manajemen Pembelajaran Bahasa Arab di Jurusan Hubungan Internasional Universitas Sriwijaya Indralaya) Ad-Dhuha Vol. 1, No. 2, 2020

Faiqoh, Nurul, "Manajemen Pembelajaran Bahasa Arab di Sekolah (studi kasus di SMK muhammadiyah playen yogyakarta)" Jurnal At-Tafkir Vol. X, No. 1, 2017.

Roviin, "Teacher Management In Arabic Instruction" Jurnal At-Ta'dib, Vol. 20, No. 22017

Suprihatin, Siti, "Upaya Guru dalam Meningkatkan Motivasi Belajar Siswa" dalam Jurnal Promosi: Jurnal Pendidikan Ekonomi UM Metro, Vol. 3, No.1 2015

Wijaya, Muallim, "Manajemen Pembelajaran Bahasa Arab Sinergi dan Praktek", A-Tanzim Vol. 1, No. 12017 